\title{
A DEFENSIVE ROLE OF IgE-MEDIATED REACTION IN THE NOSE
}

MINORU OKUDA, M.D. TOKUJI UNNO, M.D.

Dept. of Otolaryngology, Wakayama Medical College, Wakayama

(Director: M. Okuda, M.D.)

\begin{abstract}
Immunoglobulins of different classes are known to play a role in humoral defense mechanism, and Immunoglobulin E, without any actual evidence, is also expected to perform the same function. From the point of the defensive role, the present study was undertaken in nasal allergy by observing the way in which powdered carbon particles previously insufflated in the nasal cavity are rapidly removed in the nasal provocation test with causative allergen extract.

The ratio of disappearance time of the carbon powder after/before the provocation test decreased markedly in good proportion with the intensity of the provocative reaction. Both sneezing and nasal secretion provocated by allergen contributed to this removal of the powder. When the nasal cavity in one side wastested, the non-tested side also showed a rapid disapp arance of the powder.

In conclusion, Immunoglobulin $\mathrm{E}$ serves as a gate keeper by removing allergens from the surface of the nasal mucous membrane and by inhibiting the penetration of allergens into the nasal mucosa.
\end{abstract}

$79 \mathrm{~A}-0667,32821$

\section{鼻における $\operatorname{IgE}$ による反忍の生体防御作用}

\author{
和歌山県立医大耳蚝咽喉科学教室（主任：奥田 稳教授）
}

奥田稔・海野徳二

各種の免疫グロブリンは免疫反応により生体防御的役 割を果している。しかし Ishizaka (1966) 12により新し く発見された免疫グロブリン E ( IgE) の防御的意義は 明らかでない 著者 $\left(1969^{22}, 1972^{3)}\right)$ は IgE の機能の 一つは，鼻粘膜表面の抗原の粘膜内侵入阻止であるの を，放射性同位元素 ${ }^{125} \mathrm{I}$ 標識ブタクサ花粉抗原を用いて 証明した。この侵入阻止の主要なメカニズムは, 発症で 生したくしやみ，水性舅汁が粘膜表面の異物を除去する ことと考え，今回ヒトで実験的に証明した。

\section{実験方法}

1. 鼻粘膜表面炭䉼消失時間の測定

著者 (1962) 占がすでに测定法を発表した，座位で，あ らかじめ擤舜または吸引で鼻内鼻汁を完全に、粘膜を刺 激しないよう除去した後, 純植物性活性炭末(片山化学) をルーツエ吹粉器で両側鼻腔一面に一様に撒布した，炭 末䊉子の大きさは $0.1 \sim 10 \mu$, 量汢一側約 $10 \mathrm{mg}$ であつ
た。撒布後正常呼吸下に鼻鏡検查を行い，炭末が中勫甲 介, 下鼻甲介の前端, 中隔の一部に限局して僅かに付着 する程度に鼻内加消失する時間を測定し，これを消失 時間 (CDT, carbon disappearance time) とした。

2. 鼻汁量の測定

あらかじめ重量を測定した防水紙（薬包紙）で両側を 擤舅させ，得られた舅汁の重量を測定した。この際勗内 から過剩の鼻汁が完全に消失するのを鼻鏡挨査で確かめ た，鼻汁に混じた炭粉の重量は $20 \mathrm{mg}$ 以内なので無視し t.

3. 誘発後の炭粉消失時間の測定

成人ハウスダスト䙹アレルギー患者53人の CDTをま 才゙測定し,つついて炭粉末撒布後, 生理的食塩水で湿 潤した対照ディスク(トリイ)を右下鼻甲介前端に付着 させ，CDT を測定した，次に過剩奥汁除去後再び炭粉 未を撒布，右下鼻甲介を生理的食塩水で湿潤した誘発デ 
イスク（トyイ）で誘発した、ディスク含有ハウスダス

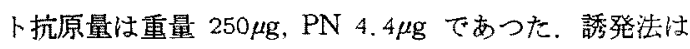
すでに著者ら(1971) ${ }^{5)}$ が発表した。誘発反応の強さ， CDTを测定した.

\section{4. 㺞學後炭粉消失時閒の测定}

正常鼻で, 下気道に著変のない成人 16 人の CDT をま ず測定し，ついで過剩の鼻汁がないのを確めた後再び炭 粉を撒布，直ちに一側づつ交互に 3 回強く睤鼻させ，以 後は正常呼吸のまま CDT を測定した。

また上記 12 人に炭粉撒布し，炭粉が消失するまで擤鲵

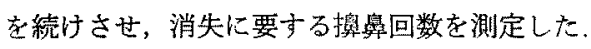

さらに副鼻腔炎，上気道疾患のない成人鼻アレルギー で, 過剩の鼻汁を有する17人に炭粉撒布後直ちに罘鼻さ せ，消失に要する擤鼻回数，鼻汁量を測定した。

\section{実験成縤}

1. 奥アレルギー 53 人の平均 CDT は右 14.4 分, 左 14.8分であつたＵさっづき測定された2回目のCDT は平均右16.5分, 左14.6分であつた。 また対照ディス夕 負荷後の CDT は負荷側で15.4分であつた。

2. 誘発後 CDI は著じるしく短縮した，誘発後／前 の比を求めると, 誘発の強さ $3+$ で $0.17 \pm 0.10,2+$ で $0.23 \pm 0.15,1+$ で $0.59 \pm 0.54,0$ で $1.06 \pm 0.46$ で, 誘 発反応の強さと CDT の短縮は中央值デストで $\mathrm{P}<0.01$ で有意に相関した（表 1)。この短蹜は非誘発側にもみ

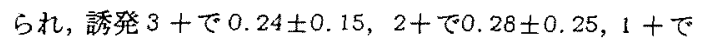
$0.54 \pm 0.31,0$ で $0.91 \pm 0.28$ であっ（表 1 ) 誘発反応 の強さは，〈しや功，水性悬汁，粘膜腫脹の3つの5

表 1 炭粉消失時間上誘発反応の強さ

\begin{tabular}{c|c|c|c|c}
\hline \multicolumn{2}{l|}{} & 例 数 & 誘 発 側 & 非誘発側 \\
\hline 及 & $3+$ & 12 & $0.17 \pm 0.10$ & $0.24 \pm 0.15$ \\
态 & $2+$ & 17 & $0.23 \pm 0.15$ & $0.28 \pm 0.25$ \\
強 & $1+$ & 12 & $0.59 \pm 0.54$ & $0.54 \pm 0.31$ \\
さ & 0 & 12 & $1.06 \pm 0.46$ & $0.91 \pm 0.28$
\end{tabular}

数字は誘発後／前の炭粉消失時間の比

表 2 學汁量と誘発反応の強さ

\begin{tabular}{|c|c|c|c|}
\hline & & 例 数 & 舅 汁 量 ( $\mathrm{g}$ ) \\
\hline \multirow{4}{*}{$\begin{array}{c}\text { 反 } \\
\text { 念 } \\
\text { 強 } \\
\text { 足 }\end{array}$} & $3+$ & 4 & 0.88 \\
\hline & $2+$ & 7 & 0.78 \\
\hline & $1+$ & 3 & 0.23 \\
\hline & 0 & 7 & 0.15 \\
\hline
\end{tabular}

ち, 症状が1つ以下を0, 症状 2つを $1+3,3$ つくし やみ 5 以下を $2+， 6$ 以上を $3+$ とした。

発症加消失史での平均時間は右 93.9 秒，左 148.1秒 であつた。

3. 唀発後/前の CDT の平均は0.33, 鼻汁量の平均 は0.51gであり，個々で，而者は $\gamma=-0.57$ (相関係数) で $\mathrm{P}<0.01$ で有意に相関し，鼻汁が多けれ短縮む大き 加つ地。

また悬汁量と諉発反応の強さも中央值テストで， $\mathrm{P}<$ 0.05 と有意に相関し, 誘発 $3+$ で $0.88 \mathrm{~g}, 2+$ で $0.78 \mathrm{~g}$, $1+$ で $0.23 \mathrm{~g}, 0$ ○ $0.15 \mathrm{~g}$ であつた（表 2)

4. 鼬鼻 3 回で消失時間は短縮し, 舅鼾後/前比は右 $0.39 \pm 0.28$, 左 $0.33 \pm 0.33$ であつた。

炭粉消失に要する舅鼻回数は，過剩鼻汁か゚なければ $1 \sim 14$ 回, 平均4.4回，鼻汁があれば $1 \sim 5$ 回，平均1.6 回であつた。

\section{考 繁}

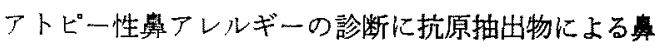
粘膜誘発反応が古くからルーチンに用いられている6 1）扢こる反応は鼾アレルギ一症状と同一であり，2）鼻 アレルギー患者に抗原特異的な即時型反応であり，3） 血清中 IgE 抗体量上相関があり，4）諉発後鼻汁好酸 球，好塩基性細胞が增加 L，5）特異的減感作療法や抗 ヒスタミン剂の投与で減弱し，6）抗原のかわりに抗七 ト IgE 血清の誘発でも上記現象がみられ，7）III，N型 アレルギーでは抗原誘発にみられるくしやみ，大量の水 性番汁はみられず，誘発にみられる症状は，花粉症なと の吸入性アトピー性舅アレルギーに特異的であるなどの

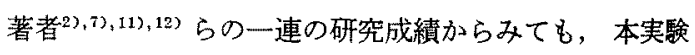
の抗原唀発による発症の主要なメカニズムはアトピー性 アレルギーと考えてよかるう。

本実験の CDT の短縮は，発症後短時間でおき，発症 しなければおこらないので，発症によるくしやみ，水性 畀汁が症粉除去に働いたと考えてよからう。

くしやみ，水性鼻汁に異物除去能があるといわれてい るが，詳細な実験データに接することができなかつた。 本実験で，〈しや夕，水性分泌の程度が強ければ，CDT の短縮も大きいのは証明されたが，両者の関与を別々に 検討するのは，両者を别々に誘起できないため困難であ つた。そこでおなじ呼気を利用した異物除去法である擤

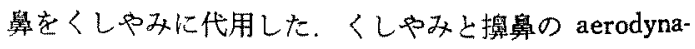
mics body plethysmography $と$ Krough spirometry で測定したが，呼帯相の持続時間は前者 $627.5 \mathrm{msec}$, 後 
者 $800 \mathrm{msec}$, 最大流速は前者 5.77LPS, 後偖 3.20 LPS, 呼気量は前者 $1.65 \mathrm{~L}$ ，後者 $1.8 \mathrm{~L}$ で類似していた。

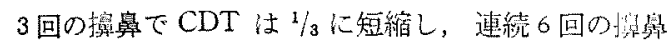
で炭粉法消失し，くしやみによる照物除去能の強さを推

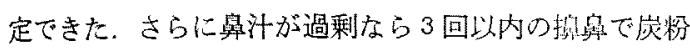
活消失し，率アレルギーの上うに過剩分泌のある㭧者で はCDTがさらに短かかつた。

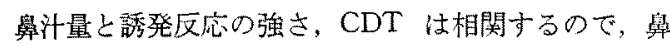
汁の分泌が異物除去に侽くのが示唆された。くしやみ文 伴わない誘発 $1+$ で，鼻汁㖏が $0.23 \mathrm{~g}$ で，消失時閒 は0.59に短樎した。それ文，鼻汁は粘膜表面を洗浄 し，くしやみによる異物除去を容易にし，異物除去に墈 くと考えられる。

さらに舆味あるのは右舅腔刺激で左にもCDT の短縮 がみられた。くしやみによる呼気は両側學腔を通り異物 除去に棣くが，そのほかに一倒刺激で他側に分泌元谯が

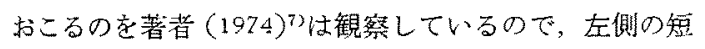
㴼に鼻汁む関与しているし考えている。

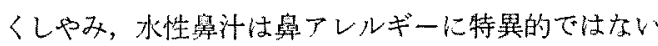
が，アレルギーで誘発された両者が粘膜表面の異物考除 去するのが実証された，IgE 反応による暴物除去は Rothwell (1972), Kelly（1972）が青生虫で報告している が，気道ではこの考えは提出されていない，最近 Steinberg (1974) が IgE 反応で透過性の增した血管加ら IgG 抗体が局所に移動し，防御に働くと報告している。著者 $(1973)^{72,113}$ は粘膜内に侵入した抗原に対しては $\operatorname{IgG}$ 抗 体の移動による抗原の中和，血流停止による抗原の血流

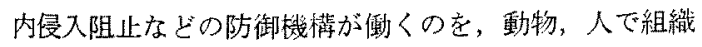
学的に, 微少循環の動的盶察から, また組織内に注入さ れた標識抗原のクリアランスから検討した。すなわら組 織内に侵入した抗原は，これを局所にとどめ，循環血流 への流入を阻止るるが，それよりも，粘膜表面の異物を 排除して抗原の粘膜内侵入阻止するメ力二ズムは生体 の防御反応としてより積極的な憼義がある。 IgEによる 反応は粘膜内侵入阻止，血流内侵入阻止に働くが，特に 前者は注目されるべきである。しかしながらこの防御反

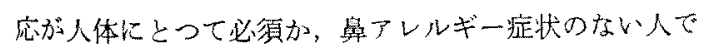
は，これにかわりどんな抗原の除去法があるかさららに梌 㘧の必要がある。

\section{ま}

鼻粘膜における IgE アレルギ一反店の結果沽こるく

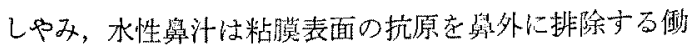
きがある。これが $\lg$ E 反応の生体防御作用の一つと考
えられた。

女 献

1) Ishizaka, K., Ishizaka, T.: Human reaginic antibodies and Immunoglobulin E. J. Allergy 42, 330$363,1968$.

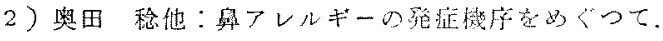
フレルキー，18, 653-691, 1969.

3) Okuda, M.: Mechanism and pathogesis of ragweed pollen nasal allergy. Wakayama Med. Report 15, 143-152, 1972 .

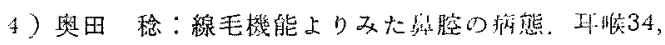
$579-582,1962$.

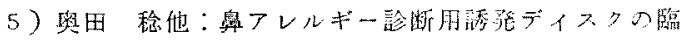
束的棘討。耳喉43，225-230，1971.

6) Sherman, W.B.: Hypersensitivity Mechanism and Management. W.B. Saunders Co. 1968.

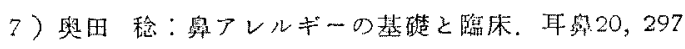
$-344,1974$.

8) Rothwell, T.L.W., Dineen, J.K.: Cellular reactions in gunea-pigs following primary and challenge infection with Trichostrougylus colubriformis with special reference to the roles played by eosinophils and basophilis in rejection of the parasite. Immunol. 22, 733-745, 1972.

9) Kelly, J.D., Ogilvie, BM.: Intestinal mast cell and eosinophil numbers during worm expulsion in nulliparous and lactating rats infected with Nippostrongylus brasiliensis. Int. Arch. Allergy 43, 497$508,1972$.

10) Steinberg, P., Ishizaka, K., Norman, P.S.: Possible role of $\mathrm{IgE}$ mediated reaction in immunity. I. Allergy 54, 359-366, 1974.

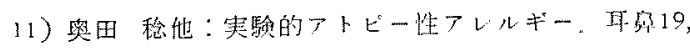
$451-457,1973^{\circ}$

12) Okuda, M.: Response of the human nasal mucous membrane to anti-human $\operatorname{IgE}$ serum. Arh. Oto-Rhino-laryng. 211, 25-33, 1975.

(本詇交の要旨好第25国日本フレルギー等全総令で㬍婊 した）

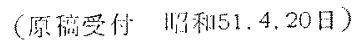

